\title{
PELATIHAN PENGEMBANGAN MEDIA PEMBELAJARAN INTERAKTIF BERBASIS MULTIMEDIA SEBAGAI UPAYA MENINGKATKAN KOMPETENSI PROFESIONALISME DAN KREATIVITAS GURU-GURU SMA MUARO JAMBI
}

\author{
Afrida, Harizon, Abu Bakar dan Aulia Sanova \\ Staf Pengajar Program Studi Pendidikan Kimia, Jurusan PMIPA FKIP Universitas Jambi \\ Email: risetida73@gmail.com; harizon16@yahoo.com; bakarabu199@yahoo.com; \\ au_sanova@yahoo.com
}

\begin{abstract}
ABSTRAK
Saat ini media pembelajaran multimedia berbasis teknologi informasi dan komunikasi (TIK) telah banyak dalam proses pembelajaran sebagai bentuk pengembangan media pembelajaran yang interaktif dan dapat menarik minat, perhatian dan motivasi belajar bagi para peserta didik. Namun yang menjadi salah kendala adalah kurang dikuasainya teknologi pengembangan multimedia pembelajaran berbasis TIK oleh para pengajar. Oleh karena itu diperlukan suatu kegiatan guna meningkatkan kualitas profesional dan kreativitas guru dalam mengembangkan multimedia.Metode yang digunakan dalam kegiatan ini demonstrasi dan praktek pembuatan multimedia menggunakan software 3D Pageflip Professional serta penugasan bagi guru-guru untuk membuat sebuah media pembelajaran hasil kreativitas peserta dan di akhir kegiatan para peserta akan diberikan penilaian hasil evaluasi produk dan respon peserta terhadap kebermanfaatan kegiatan. Berdasarkan hasil pengamatan, bahwa para guru rata-rata memiliki kemampuan yang sangat baik dengan skor 89,63 dalam memahami urgensi pengembangan media pembelajaran, mampu membuat media pembelajaran, mengenal fungsi program, dapat memasukkan teks dan menyisipkan objek movie, sound dan gambar ke ruang template 3D Pageflip Professional. Selanjutnya berdasar hasil angket, rata-rata guru memberikan tanggapan yang sangat baik dengan skor sebesar 82,67 karena melalui kegiatan ini para peserta memperoleh manfaat berupa pengetahuan tentang operasionalisasi program dan uji kreativitas guru dalam membuat desain pengembangan media sebagai bahan ajar.
\end{abstract}

\section{Kata kunci: Professionalism, Creativity, Teacher, Multimedia}

\section{PENDAHULUAN}

Guru merupakan salah satu komponen utama bidang pendidikan yang menjadi faktor penentu tinggi rendahnya kualitas hasil pendidikan. Oleh karena itu, guru dituntut untuk dapat mengikuti perkembangan teknologi informasi dan komunikasi. UU Guru dan Dosen No.14 Tahun 2005 yang menyebutkan bahwa seorang guru harus mempunyai kompetensi pedagogik, kepribadian, sosial, dan profesional. Terkait kompetensi profesional, dalam PP Nomor 74 Tahun 2008 menjabarkan bahwa diharapkan memiliki kemampuan dalam menguasai pengetahuan di bidang ilmu pengetahuan, teknologi, dan/atau seni dan budaya. Sehingga dalam hal ini, profesionalisme seorang guru bukan hanya sekedar mengajar (trasfer of knowledge) melainkan setiap guru diharapkan mampu menciptakan kondisi belajar yang menantang kreativitas dan aktivitas siswa, memotivasi siswa, menggunakan multimedia, multimetode, dan multi sumber agar mencapai tujuan pembelajaran yang diharapkan ( Rusman, 2011). 
Pesatnya perkembangan teknologi informasi dan komunikasi atau yang dikenal dengan istilah Information and Communication Technology (ICT) telahmerambah berbagai bidang kehidupan tidak terkecuali bidang pendidikan dan pengajaran. Hal ini dibuktikan dengan tersedianya berbagai media pembelajaran yang didasarkan pada pandangan konstruksi pengetahuan. Dalam perkembangannya, media dapat digabung dengan media lain yang disebut dengan multimedia. Secara umum multimedia adalah menggunakan beberapa media untuk menghadirkan informasi yang merupakan kombinasi antara teks, grafik, animasi, gambar, video dan suara (Ivers, dkk, 2002). Pembelajaran berbasis multimedia dengan bantuan piranti komputer dalam bentuk gambar dua dimensi maupun tiga dimensi, tampilan teks yang interaktif, efek animasi (gambar bergerak), kombinasi warna yang menarik serta alat bantu suara (audio) yang membantu siswa memahami materi dengan lebih mudah.

Berdasarkan wawancara kepala sekolah dan salah satu gurudi SMA Negeri 11 Muaro Jambi, mayoritas guru yang mengajar berada di kisaran usia produktif sehingga mempunyai pengetahuan tentang komputer (computer literacy) yang cukup baik. Namun demikian, masih banyak guru-guru yang belum maksimal memanfaatkan teknologi informasi untuk mendukung kegiatan akademis dan proses pembelajaran masih berlangsung secara konvensional dan monoton, dimana aktivitas menulis lebih dominan.

Media pembelajaran berbasis komputer bagi guru SMA Negeri 11 Muaro Jambi dirasakan sangat penting, karena dapat menunjang kualitas proses belajar mengajar dan profesionalisme guru. Untuk menunjang pengembangan media pembelajaran yang lebih baik dan menarik, para guru diarahkan untuk memaksimalkan pemanfaatan teknologi informasi dan aplikasi komputer berbasis multimedia interaktif yang bertujuan untuk memperkaya konten materi yang akan disampaikan dan dapat memfokuskan perhatian siswa dalam belajar. Oleh karena itu, maka tim pengabdi tergerak untuk berupaya menyelenggarakan kegiatan pelatihan pengembangan multimedia interaktif untuk meningkatkan kompetensi dan kreativitas guru.

\section{METODE PELAKSANAAN}

Untuk merealisasikan kerangka pemecahan sebagaimana dijelaskan diatas, tim pengabdi melakukan koordinasi dalam bentuk analisis kebutuhan dan ketersediaan fasilitas TIK, selanjutnya tim melakukan sosialisasi dan perijinan dengan Kepala SMA 11 Muaro Jambi sebagai pihak stake holder serta mendiskusikan beberapa hal yang berkaitan dengan teknis pelaksanaan kegiatan pengabdian yang meliputi waktu pelaksanaan, lokasi dan materi pelatihan.

Dalam pelatihan ini tim pelaksana mengundang 18 guru semua bidang studi yang mengajar di SMA Negeri 11 Muaro Jambi. Selanjutnya kepada para peserta akan diberikan materi dan praktek pelatihan pemanfaatan multimedia berbasis komputer bagi semua guru bidang studi.

Ada tiga metode yang diterapkan dalam pelatihan ini, yaitu metode presentasi, metode demonstrasi dan metode praktik. Metode presentasi diterapkan dalam pengenalan software, kemanfaataannya dan penerapannya dalam pembuatan media pembelajaran interaktif, metode demonstrasi mengenai pengoperasionalisasian program dan metode praktik dimana guru-guru 
mempraktikkan secara langsung pembuatan media pembelajaran sesuai mata pelajaran masing-masing dengan pemanfaatan program 3D Pageflip Professional .

Sebagaimana solusi yang ditawarkan, kegiatan pengabdian ini akan dilaksanakan dalam beberapa tahapan sebagai berikut :

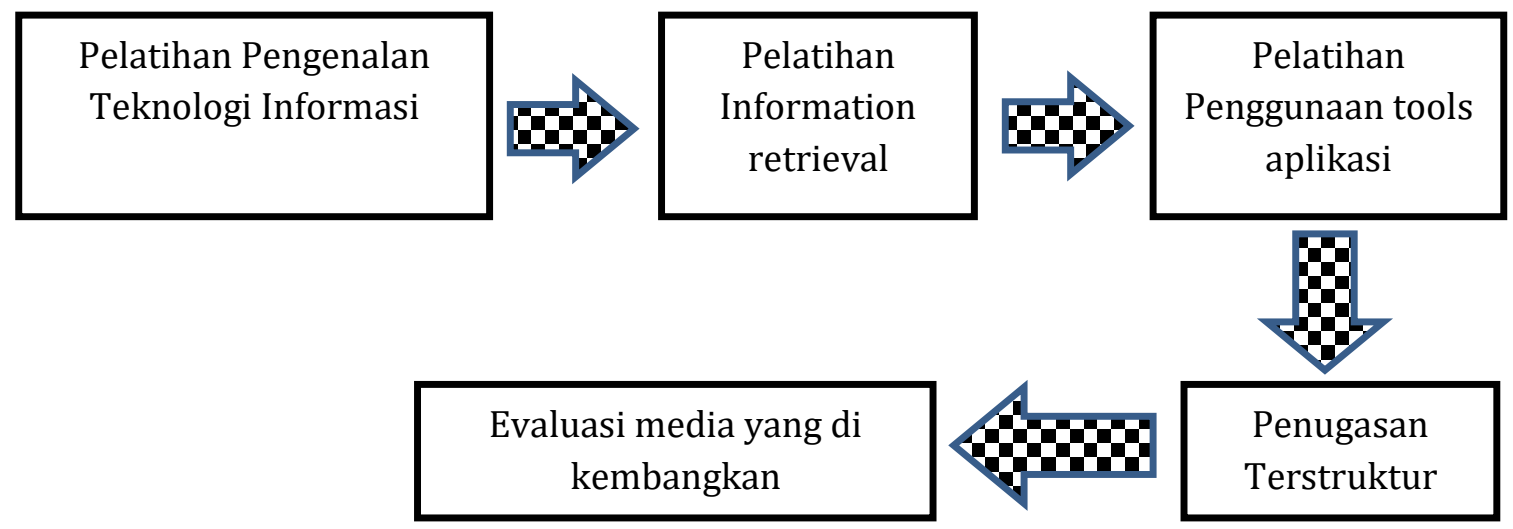

Gambar 1. Tahapan Pelaksanaan Kegiatan

Melalui pelatihan pengenalan teknologi informasi diharapkan peserta dalam hal ini guru di lingkungan SMA Negeri 11 Muaro Jambi dapat menambah wawasan dan pengetahuan tentang perkembangan teknologi informasi, khususnya penerapan media teknologi informasi dalam menunjang pembelajaran, sehingga peserta dapat mengimplementasikan secara maksimal dalam proses belajar mengajar.

Pelatihan temu kembali informasi (Information Retrieval) dilakukan dengan pelatihan pemanfaatan media internet untuk pengayaan konten materi ajar melalui pengumpulan informasi yang akurat, kredibel dan terjamin validitasnya.

Pelatihan penggunaan tools aplikasi dapat menambah wawasan dan pengetahuan para guru untuk dapat menggunakan tools aplikasi dan multimedia yang mendukung dalam pengembangan media pembelajaran yang menarik dan berkualitas. Tools aplikasi yang akan dikenalkan penggunaannya adalah program 3D Pageflip Professional.

Penugasan pembuatan media pembelajaran berbasis multimedia bagi peserta pelatihan untuk menyusun media pembelajaran sesuai dengan bidang/mata pelajaran masing-masing untuk keperluan proses belajar mengajar.

Evaluasi media pembelajaran yang dikembangkan dilakukan dengan memberi kesempatan bagi para peserta untuk berkonsultasi secara kelompok dengan narasumber mengenai konten dan media pembelajaran yang dikembangkan dan para narasumber memberi saran perbaikan agar media pembelajaran yang dihasilkan menjadi semakin berkualitas.

\section{HASIL YANG DICAPAI}

Kegiatan pelatihan ini di mulai pada hari Sabtu tanggal 27 Agustus 2017 dengan di ikuti sebanyak 18 peserta guru bidang studi. Multimedia berbasis e-learning yang kami gunakan dalam kegiatan pengabdian adalah software program 3D Pageflip Professional. Sofware ini memiliki fitur publikasi dengan berbagai macam tipe baik untuk kebutuhan online maupun offline dengan menampilkan e-book dalam bentuk majalah 3 dimensi yang lebih nyata dan menarik dengan adanya sound, video, sertaanimasi yang bisa ditampilkan beserta editor yang 
lengkap dengan bahan yangdigunakan bisa berasal dari PDF maupun microsoft power point. Para pengguna pun dapat menggunakan aplikasi ini dengan mudah melalui smartphone, tablet dan gadget dengan merubah format file atau exe menjadi 3dp, sehingga dapat digunakan sebagai pembelajaran mandiri, kapan pun dan dimanapun.

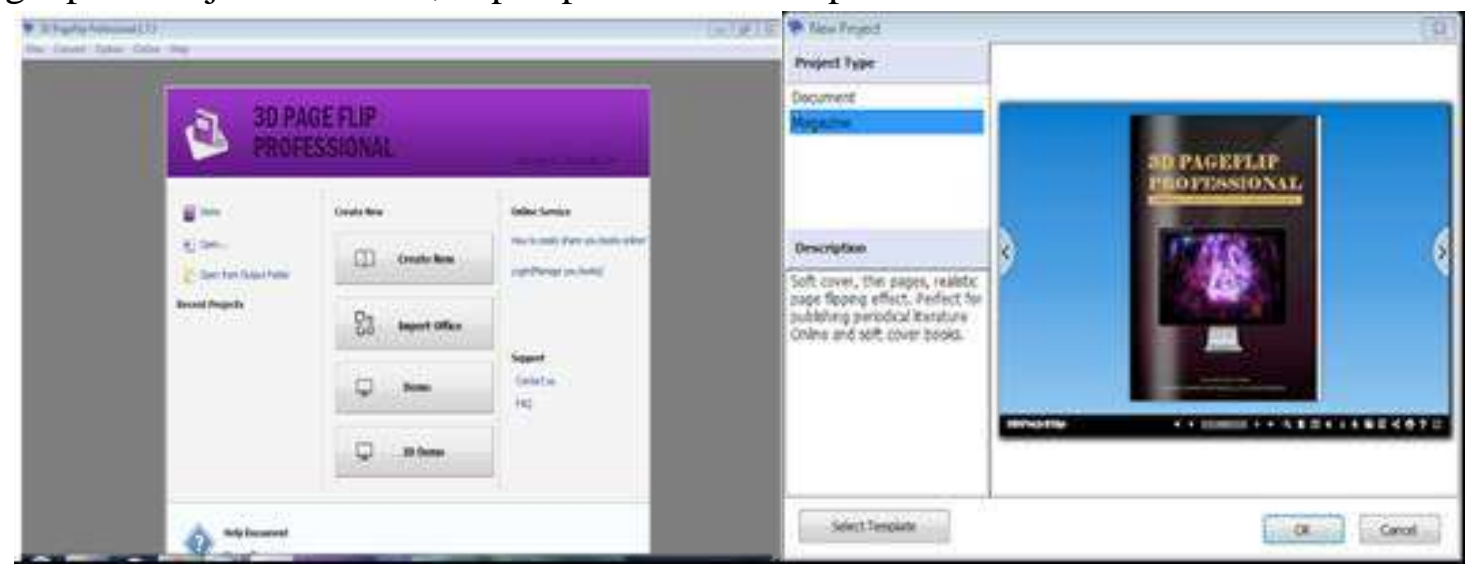

Gambar 2. Tampilan Aplikasi dan Template 3D Pageflip Professional

Dalam pelaksanaan program ini melibatkan mahasiswa untuk membantu proses pembimbingan dan praktik agar kegiatan dapat berjalan lancar. Kegiatan tanya jawab dilakukan bersamaan dengan penyajian materi. Para peserta dapat langsung berdiskusi dengan para pemateri secara langsung untuk memahamkan materi dan sharing pengalaman terkait dengan masalah yang tengah dibahas dalam materi bersangkutan.

Adapun langkah yang telah ditempuh dalam pelaksanaan kegiatan pelatihan ini mencakup beberapa tahapan sebagai berikut :

\section{Persiapan}

Tahap persiapan merupakan tahap awal sebelum pelaksanaan PPM. Dalam tahap ini ada beberapa hal yang dilakukan, yakni koordinasi internal, dilakukan oleh tim untuk merencanakan pelaksanaan secara konseptual, operasional, serta job description masingmasing anggota, penentuan dan rekruitment peserta pelatihan. Dalam pemilihan peserta dipersyaratkan yang telah memiliki kemampuan yang memadai di bidang computer. Disamping itu juga di perlukan persiapan pembuatan instrumen kegiatan, meliputi lembar presensi, angket, lembar kerja, persiapan konsumsi, publikasi, lokasi, dokumentasi, dan sebagainya.

\section{Pelaksanaan Pelatihan}

Tahap ini merupakan tahap pelatihan yang diberikan kepada para semua guru-guru bidang studi SMAN 11 Muaro Jambi yang memiliki kecakapan dan terampil dalam mengaplikasikan komputer dasar. Pelaksanaan pelatihan ini mencakup beberapa hal berikut :

\section{a. Penyajian Materi}

Pelatihan ini memberikan beberapa materi yang disajikan terkait dengan pengertian, fungsi, manfaat dan urgensi multimedia interaktif agar pembelajaran yang diberikan oleh guru menjadi lebih atraktif sehingga meningkatkan minat dan kualitas belajar siswa dalam proses pembelajaran. Materi selanjutnya adalah presentasi tentang pengenalan dan penggunaan program 3D Pageflip Profesional untuk pembuatan media pembelajaran. Melalui pelatihan pengenalan teknologi informasi diharapkan peserta dalam hal ini guru di lingkungan 
SMAN 11 Muaro Jambi dapat menambah wawasan dan pengetahuan tentang perkembangan teknologi informasi, khususnya penerapan media teknologi informasi dalam menunjang pembelajaran, sehingga peserta dapat mengimplementasikan secara maksimal dalam proses belajar mengajar. Kemudian dilanjutkan dengan kegiatan pelatihan praktek yang berupa Information Retrieval untuk membantu para guru dalam mencari dan mengumpulkan bahan untuk pengayaan konten materi ajar yang akan disampaikan melalui pengumpulan informasi yang akurat, kredibel dan terjamin validitasnya, meliputi kegiatan mencari sekumpulan teks, gambar, animasi maupun video pembelajaran.

Setelah para peserta telah menyiapkan bahan ajar dalam bentuk serangkaian teks, gambar, animasi maupun video pembelajaran, maka para peserta pelatihan di beri pengenalan tools aplikasi program 3D Pageflip Professional. Kemudian para peserta menyiapkan bahan ajar dalam bentuk microsoft word atau powerpoint dengan dan di konversikan menjadi adobe acrobat PDF dan gambar menjadi bentuk buku dalam ruang 3D dan peserta di beri pengetahuan bagaimana cara memasukkan video atau gambar dalam ruang buku $3 D$ Pageflip Professional.

Pelatihan penggunaan tools aplikasi dapat menambah wawasan dan pengetahuan para guru untuk dapat menggunakan tools aplikasi dan multimedia yang mendukung dalam pengembangan media pembelajaran yang menarik dan berkualitas, serta memberikan keterampilan kepada para guru dalam mengembangkan perangkat ajarnya yang berbasis multimedia dengan metode pendampingan pelatihan dengan membagi peserta menjadi beberapa kelompok dan setiap kelompok didampingi oleh tim pengabdi. Proses pendampingan ini dilakukan untuk mempermudah peserta dalam memahami materi praktek pelatihan.

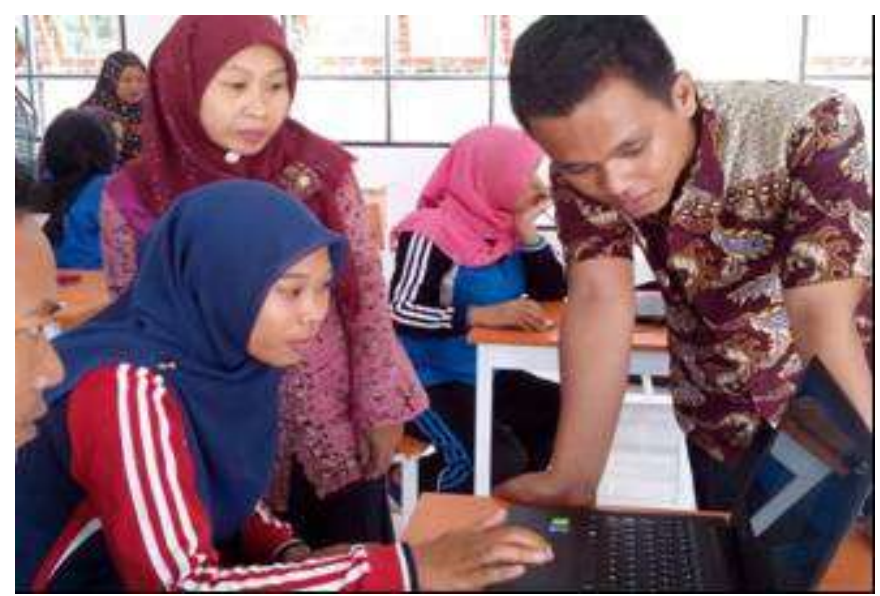

Gambar 2 Pendampingan Praktek Pelatihan Multimedia

Materi yang disajikan dapat diterima, dicerna, dan dipahami peserta dengan baik. Jumlah peserta yang sebanding dengan jumlah pengabdi yang berperan sebagai instruktur dan tutor menjadikan pelatihan ini menjadi lebih kondusif. Hal ini didukung pula dengan kemampuan peserta di bidang komputer yang telah cukup menguasai komputer dasar sehingga pelatihan dapat berjalan lancar dan para peserta dapat berkomunikasi dengan para pembicara dan peserta lain dengan lebih baik. 


\section{b. Penugasan Praktik}

Pada akhir materi peserta diberi tugas praktik pelatihan pembuatan media bahan ajar dengan bantuan program 3D Pageflip Professional sesuai materi yang telah disajikan untuk menggali penyerapan dan pemahaman materi serta melihat kreativitasnya dalam berkarya. Dalam pelatihan ini para guru ditugaskan untuk membuat satu media pembelajaran terkait mata pelajaran yang diampu masing-masing guru. Dalam hal ini, tim pengabdi berupaya untuk mendampingi, memandu dan mengarahkan serta memberikan solusi apabila timbul permasalahan selama penugasan praktik.

\section{c. Evaluasi dan Penyempurnaan Karya Media Pembelajaran oleh Tim}

Evaluasi kegiatan dilakukan selama proses kegiatan berlangsung, yaitu pada saat peserta kegiatan melaksanakan proses penugasan membuat multimedia pembelajaran maupun pada saat akhir kegiatan. Teknik evaluasi kegiatan PPM ini dilakukan dengan beberapa cara, baik dari pengamatan keterampilan peserta maupun penyebaran angket untuk melihat responsif guru terhadap proses kegiatan yang di tinjau dari kebermanfaatan kegiatan pelatihan dan pengetahuan tentang proses pembuatan multimedia pembelajaran.

Selama proses penugasan, tim pengabdi melakukan penilaian kemampuan dan kreativitas guru-guru selama praktik kegiatan. Data hasil pengamatan selama proses penugasan dapat di lihat pada tabel berikut ini :

Tabel 1. Lembar Penilaian Kemampuan Peserta

\begin{tabular}{lccc}
\hline \multicolumn{1}{c}{ Aspek yang dinilai } & Total skor & \% Skor & Kategori \\
\hline Mengenal Program dan Tools & 70 & 97,22 & SB \\
Memasukkan teks bahan ajar & 62 & 86,11 & SB \\
Menyediakan tamplate & 65 & 90,28 & SB \\
Menyisipkan objek movie, sound, & 67 & 90,54 & SB \\
gambar dan efek animasi & & & \\
Membuat tombol & 62 & 86,11 & SB \\
Membuat soal atau quiz interaktif. & 63 & 87,50 & SB \\
Jumlah & 389 & 537,76 & \\
\hline Rata-rata total skor & & $\mathbf{8 9 , 6 3}$ & SB \\
\hline
\end{tabular}

Berdasarkan hasil pengamatan, dapat dilihat bahwa para guru rata-rata memiliki kemampuan dan kreativitas yang sangat baik dengan rata-rata skor sebesar 89,63. Dalam hal ini guru di nilai telah mampu membuat media pembelajaran interaktif, mengetahui fungsi masing-masing tools 3D Pageflip Professional, memasukkan teks, dapat menyediakan template yang dapat diaplikasikan untuk menyusun materi pembelajaran, menyisipkan objek movie, sound, gambar dan efek animasi, membuat tombol dan juga dapat membuat soal atau quiz interaktif. Hasil penilaian akhir ini, menggambarkan indikator keberhasilan materi yang telah disajikan. Selain itu, secara proses juga dicermati kinerja dan kesertaan para peserta.

Pada akhir pelatihan, hasil karya multimedia yang telah dibuat oleh para guru dikumpulkan dan dinilai oleh tim pengabdi kemudian dilakukan evaluasi kembali oleh tim pengabdi dalam bentuk saran dan masukan guna penyempurnaan produk yang telah dibuat. Kemudian 
dikembalikan kembali kepada peserta untuk di revisi sesuai dengan saran dan masukan agar dapat digunakan untuk mengajar.

\section{d. Refleksi dan Penutupan Program PPM}

Di akhir kegiatan peserta dan tim melakukan refleksi hasil pelatihan dan para peserta juga memberikan evaluasi hasil kegiatan pelatihan ini dengan memberi respon atau tanggapan hasil kegiatan menggunakan pengolahan hasil skor dalam bentuk skala likert dengan interval : 5-10 : tidak baik, 11-15 : cukup baik, 16-20 : baik dan 21-25.

Dari hasil secara keseluruhan dapat disimpulkan bahwa rata-rata respon para peserta terhadap kegiatan pelatihan multimedia sangat baik dengan skor sebesar 82,67. Melalui pelatihan ini, para peserta memperoleh manfaat dari program pelatihan ini untuk meningkatkan kualitas media pembelajaran, mengetahui cara pengoperasionalisasian program serta mampu membuat media pembelajaran sesuai dengan mata pelajaran yang diampu masing-masing peserta.

Setelah semua kegiatan yang telah direncanakan terlaksana, ketua tim pengabdian menutup program dan memberikan pesan kepada segenap peserta pelatihan untuk mencoba berinovasi membuat media bahan ajar berbasis multimedia pada materi bahan ajar lainnya dan dapat mengimplementasikannya dalam kelas untuk di jadikan sebagai bahan ajar, sehingga dapat menarik perhatian dan minat siswa. Begitu pula para peserta juga memberi saran dan masukan agar kegiatan pelatihan pengabdian ini di harapkan dapat berkelanjutan untuk program yang akan datang dengan pelatihan multimedia yang lebih menarik dan interaktif lagi, sebagai contoh program animasi flash dan camtasia yang dapat memberi pengetahuan pada guru bagaimana cara membuat gambar dan editing video dan menggabungkan teks, suara dan gambar secara langsung.

\section{KESIMPULAN DAN SARAN}

Berdasarkan dari hasil evaluasi kegiatan yang telah dilakukan, maka dapat disimpulkan bahwa melalui kegiatan pelatihan pembuatan multimedia pembelajaran para peserta rata-rata memiliki kemampuan yang sangat baik dengan skor 89,63 dalam mengoperasikan tools-tools aplikasi dan mampu membuat bahan ajar menggunakan program multimedia program $3 D$ Pageflip Professional. Disamping itu berdasarkan hasil angket, rata-rata guru memberikan tanggapan yang sangat baik dengan skor sebesar 82,67 karena melalui kegiatan ini para peserta memperoleh manfaat berupa pengetahuan tentang operasionalisasi program dan uji kreativitas guru dalam membuat desain pengembangan media sebagai bahan ajar.

Pelatihan multimedia yang telah dilakukan hanya terbatas kepada pemberian pengetahuan dan keterampilan guru membuat bahan ajar e-learning menggunakan program 3D Pageflip Professional. Oleh karena itu, sebagai saran dimana media yang telah di buat para guru-guru perlu di lakukan program pengabdian berkelanjutan dalam bentuk implementasi pembelajaran di kelas sebagai bahan ajar untuk melihat minat, capaian hasil belajar dan respon peserta didik di sekolah SMAN 11 Muaro Jambi.

\section{UCAPAN TERIMAKASIH}

Puji syukur Alhamdulillah kami panjatkan kepada Allah SWT yang telah memberikan hidayah dan kemudahan bagi kami untuk menyelesaikan penelitian ini dengan baik dan sesuai 
dengan jadwal yang telah ditentukan. Oleh karena itu, pada kesempatan ini rasa terimakasih tentunya kami ucapkan untuk:

1. Bapak Rektor Universitas Jambi yang telah menyetujui usulan laporan pengabdian ini.

2. Ketua Lembaga Pengabdian Kepada Masyarakat Universitas Jambi beserta stafnya yang telah membantu kelancaran administrasi dan dorongan moril maupun materil sehingga pengadian ini dapat selesai.

3. Dekan FKIP Universitas Jambi yang telah memberikan fasilitas sarana dan prasarana serta kemudahan lainnya, sehingga penelitian ini dapat diselesaikan dengan baik.

4. Kepala Sekolah SMA Negeri 11 Muaro Jambi yang telah memberi izin atas tempat dan waktunya sehingga kegiatan ini dapat berjalan lancar serta guru-guru bidang studi dan ikut berpartisipasi dalam pelaksanaan kegiatan ini.

5. Semua pihak yang telah terlibat dalam penyelesaian pengabdian ini yang tidak dapat disebutkan satu persatu.

\section{DAFTAR PUSTAKA}

Chen, R. J. 2010. Investigating Models for Preservice Teachers' Use of Technology to Support Student-Centered Learning. Computers \& Education 55: 32-42.

Departemen Pendidikan Nasional. 2005. Undang-Undang Nomor 14 Tahun 2005, Tentang Guru dan Dosen.

Ivers., Karen, S., Barron., dan Anne, E. 2002. Multimedia Project in Education: Designing, Producing, and Assessing. United States of America. Libraries Unlimites Teacher Ideas Press.

Riskiawan, H.Y., Setyohadi, D.P.S., dan Arifianto, A.S. 2016. Pelatihan Pengembangan Media Pembelajaran Berbasis Multimedia untuk Meningkatkan Kualitas Dan Kreativitas Guru SMA. Jurnal Pengabdian Masyarakat J-Dinamika. Vol. 1. No. 1. Hal 48-52.

Rusman. 2011. Model-Model Pembelajaran Mengembangkan Profesionalisme Guru. PT Raja Gafindo Persada, Jakarta. 